\title{
Karakteristik dan Motivasi Augmentasi Penis dengan Komplikasinya di RSUP Prof. Dr. R. D. Kandou dan RS Jejaring
}

\author{
${ }^{1}$ Adrian Purba, ${ }^{2}$ Ari Astram, ${ }^{2}$ Richard Monoarfa
}

\author{
${ }^{1}$ PPDS Ilmu Bedah Fakultas Kedokteran Universitas Sam Ratulangi Manado \\ ${ }^{2}$ Divisi Bedah Urologi Bagian Ilmu Bedah Universitas Sam Ratulangi/RSUP Prof. Dr. R. D. \\ Kandou Manado \\ Email: adrian@gmail.com
}

\begin{abstract}
Penile augmentation is an individual effort to enlarge one's penile size for his sexual satisfaction and his mate without functional alteration. This study was aimed to obtain the profile of motivation, sexual satisfaction, mental distortion, and complications in patients with penile augmentation. This was a descriptive categorical study with a retrospective approach. This study was conducted at Prof. Dr. R. D. Kandou Hospital and its link hospitals for 10 months involving 23 patients; most of them (34.78\%) were 26-35 years old. Most patients (61\%) had internal motivation based on NSSS scale $>30$. Based on ulcer free period, 3 patients had free period of ulcer I; no patient had free period of ulcer II. Based on pain scale, 14 patients $(60.87 \%)$ had pain scale of $<5$ and 9 patients (39.13\%) had pain scale of $>5$. Most complications were in the form of ulcers located in preputium (56.52\%). The relationships between motivation and NSSS scale before and after penile augmentation were analyzed using Fisher exact test which obtained $P=$ 0.000 for relationship between motivation and NSSS scale (sexual satisfaction) before and after penile augmentation and $P=0.360$ between post augmentation (with its complications) and sexual satisfaction. Conclusion: Patients with penile augmentation were internally and externally motivated without any mental distortion. There was a significant relationship between internal motivation and penile augmentation as well as between motivation and sexual satisfaction. Albeit, there was no significant relationship bewteen complications of penile augmentation and sexual satisfaction. Most patients suffered complications.
\end{abstract}

Keywords: penile augmentation, NSSS

\begin{abstract}
Abstrak: Augmentasi penis merupakan usaha individu untuk membesarkan ukuran penis demi memenuhi hasrat seksual dan pasangannya tanpa perubahan fungsi. Penelitian ini bertujuan untuk mendapatkan gambaran motivasi, kepuasan seksual, adanya gangguan jiwa, dan komplikasi pada pasien yang melakukan augmentasi penis. Jenis penelitian ialah deskriptif kategorik dengan pendekatan retrospektif. Penelitian ini dilakukan di RSUP Prof. Dr. R. D. Kandou dan RS jejaring selama 10 bulan yang melibatkan 23 pasien. Rentang usia pasien 16-59 tahun, terbanyak pada usia 26-35 tahun $(34,78 \%)$. Sebagian besar pasien $(61 \%)$ dengan motivasi secara internal berdasarkan skala NSSS $>30$. Berdasarkan periode bebas ulkus didapatkan 3 pasien dengan periode bebas ulkus I; tidak didapatkan pasien dengan periode bebas ulkus II. Berdasarkan skala nyeri didapatkan 14 pasien $(60,87 \%)$ dengan skala nyeri $<5$ dan 9 pasien $(39,13 \%)$ dengan skala nyeri $>5$. Lokasi komplikasi terbanyak berupa ulkus di preputium $(56,52 \%)$. Analisis menggunakan Fisher exact terhadap hubungan motivasi dan skala NSSS sebelum dan sesudah augmentasi penis memperlihatkan hubungan antara motivasi dan kepuasan seksual dengan nilai $P=0,000(<0,05)$ serta hubungan antara pasca augmentasi (beserta komplikasi) dan kepuasaan seksual dengan nilai $P=$ $0,360(>0,05)$. Simpulan: Pasien yang melakukan augmentasi penis termotivasi secara internal dan eksternal tanpa adanya distorsi gangguan psikiatrik. Terdapat hubungan bermakna antara motivasi internal dan augmentasi penis serta antara motivasi melakukan augmentasi penis dan kepuasan seksual. Tidak terdapat hubungan bermakna antara komplikasi augmentasi penis dan kepuasaan seksual. Hampir seluruh pasien disertai komplikasi.
\end{abstract}

Kata kunci: augmentasi penis, NSSS 
Augmentasi penis merupakan usaha individu untuk mengubah ukuran penis (menjadi lebih besar dan panjang) demi memuaskan hasrat seksualnya atau pasangannya tanpa perubahan fungsi. ${ }^{1-3}$ Fenomena augmentasi penis paling sering ditemukan pada laki-laki berusia 15-24 tahun. ${ }^{4}$

Augmentasi penis banyak dilakukan oleh laki-laki muda dari Asia Tenggara, termasuk tahanan di Indonesia, anggota Yakuza di Jepang, pemuda di Filipina, dan pengguna metamfetamin di Thailand. Menurut sejarah yang telah dilaporkan, benda asing yang diimplan berasal dari Thailand, Jepang, Korea, Rusia, Philipina, Jerman, Rumania, dan Asia. ${ }^{5}$ Di Indonesia, praktek implantasi benda asing ke jaringan penis secara tradisional sudah dikenal lama dan terukir dalam relief di Candi Sukuh Jawa Tengah pada abad 15 yang menggambarkan implantasi benda asing di bawah kulit penis. ${ }^{6} \mathrm{Di}$ dunia, tercatat paling banyak laporan kasus augmentasi penis ditemukan di Asia (76,92\%), terutama Asia Tenggara (90\%), Eropa Timur (17,95\%); sisanya dari negara-negara Eropa lainnya dan Amerika Selatan $(2,56 \%){ }^{7}$

Dewasa ini semakin banyak kasus augmentasi penis disertai komplikasinya didapatkan di Poliklinik Bedah RSUP Prof. Dr. R. D. Kandou dan RS jejaring. Penelitian ini bertujuan untuk mendapatkan gambaran motivasi, kepuasan seksual, adanya gangguan jiwa, dan komplikasi pada pasien yang melakukan augmentasi penis. Sebagai faktor etiologi ialah motivasi baik internal maupun eksternal yang ingin digali dari pasien dengan augmentasi penis serta karakteristik yang memengaruhi komplikasinya. Dalam hal ini augmentasi penis merupakan tujuan dari keinginan pelaku.

\section{METODE PENELITIAN}

Jenis penelitian ini ialah deskriptif kategorik dengan pendekatan retrospektif untuk mendapatkan motivasi, kepuasan, dan adanya gangguan jiwa pada pasien yang melakukan augmentasi penis di RSUP Prof. Dr. R. D. Kandou dan RS jejaring. Jumlah sampel terpenuhi sebanyak 23 pasien yang memenuhi kriteria inklusi.
Pada setiap pasien yang datang ke Poliklinik Bedah RSUP Prof. Dr. R. D. Kandou atau RS jejaring dilakukan pemeriksaan fisik dan mengisi kuesioner motivasi, kesehatan mental emosional (Self Reported Questionnair/SRQ 20), dan kepuasan seksual (New Satisfaction Sexual Scale/NSSS). Bila pada hasil kuesioner kesehatan mental emosional didapatkan simpulan adanya kelainan gangguan jiwa maka terapi dilanjutkan oleh Bagian Bedah dan Psikiatri dengan melakukan wawancara psikiatrik dan tes MMPI, yang selanjutnya dilakukan diagnosis dan klasifikasi distorsi kondisi psikiatri. Data yang diperoleh dikumpulkan dan diolah. Data hubungan motivasi dengan skala NSSS sebelum dan sesudah augmentasi penis diuji dengan Fischer exact test.

\section{HASIL PENELITIAN}

Penelitian dilakukan di RSUP Prof. Dr. R. D. Kandou dan RS Jejaring di Sulawesi Utara selama 10 bulan (Januari 2017Oktober 2017) yang melibatkan 23 pasien sesuai kriteria inklusi. Data karakteristik pasien, motivasi augmentasi penis beserta komplikasinya ditampilkan dalam Tabel 1.

Data hubungan motivasi dan skala kepuasan seksual berdasarkan NSSS sebelum dan sesudah augmentasi penis Dianalisis dan diuji dengan Fischer exact test. Hasil hubungan antara motivasi dan kepuasan seksual diperoleh nilai $P=0,000$ $<0,05$ yang menyatakan terdapat hubungan bermakna antara motivasi melakukan augmentasi penis dan kepuasan seksual. Pada hubungan antara pasca augmentasi (beserta komplikasi) dan kepuasaan seksual diperoleh nilai $P=0,360>0,05$, yang menyatakan tidak terdapat hubungan bermakna antara tindakan augmentasi penis dan kepuasaan seksual.

\section{BAHASAN}

Augmentasi penis merupakan usaha individu untuk mengubah ukuran penis (menjadi lebih besar dan panjang) demi memuaskan hasrat seksual atau pasangan tanpa merubah fungsinya. ${ }^{8,9}$ 
Tabel 1. Data karakteristik pasien, motivasi augmentasi penis beserta komplikasinya

\begin{tabular}{|c|c|}
\hline Karakteristik pasien & $(\%)$ \\
\hline $\begin{array}{l}\text { Usia } \\
12-16 \text { tahun } \\
17-25 \text { tahun } \\
26-35 \text { tahun } \\
36-45 \text { tahun } \\
46-55 \text { tahun } \\
56-65 \text { tahun }\end{array}$ & $\begin{array}{c}4,05 \% \\
23 \% \\
36 \% \\
23 \% \\
9 \% \\
4,05 \%\end{array}$ \\
\hline $\begin{array}{l}\text { Status pernikahan } \\
\text { Belum menikah } \\
\text { Menikah }\end{array}$ & $\begin{array}{l}36 \% \\
64 \%\end{array}$ \\
\hline $\begin{array}{l}\text { Latar belakang tingkat pendidikan } \\
\text { SD } \\
\text { Tidak tamat SMA } \\
\text { Tamat SMA } \\
\text { D3 } \\
\text { Perguruan tinggi } \\
\text { Tamat perguruan tinggi }\end{array}$ & $\begin{array}{c}4 \% \\
13 \% \\
41 \% \\
17 \% \\
8 \% \\
17 \%\end{array}$ \\
\hline $\begin{array}{l}\text { Jenis pekerjaan } \\
\text { Wirausaha } \\
\text { Tidak bekerja } \\
\text { PNS } \\
\text { Militer } \\
\text { Pegawai swasta }\end{array}$ & $\begin{array}{c}31 \% \\
22 \% \\
17 \% \\
26 \% \\
4 \%\end{array}$ \\
\hline $\begin{array}{l}\text { Kuesioner kesehatan jiwa dan gangguan mental } \\
\text { emosional (SRQ2O) }\end{array}$ & $0 \%$ \\
\hline $\begin{array}{l}\text { Motivasi pada pasien } \\
\text { Internal } \\
\text { Eksternal }\end{array}$ & $\begin{array}{l}61 \% \\
39 \%\end{array}$ \\
\hline $\begin{array}{l}\text { Motivasi internal yang memengaruhi augmentasi } \\
\text { penis berdasarkan NSSS } \\
\text { NSSS }>30 \\
\text { NSSS }<30\end{array}$ & $\begin{array}{l}61 \% \\
39 \%\end{array}$ \\
\hline $\begin{array}{l}\text { Augmentasi penis berdasarkan motivasi eksternal } \\
\text { Hasutan pasangan berhubungan intim } \\
\text { Hasutan teman } \\
\text { Hasutan atasan }\end{array}$ & $\begin{array}{l}11 \% \\
33 \% \\
56 \%\end{array}$ \\
\hline $\begin{array}{l}\text { Pasien dengan/tanpa komplikasi akibat } \\
\text { augmentasi penis } \\
\text { Dengan komplikasi } \\
\text { Tanpa komplikasi }\end{array}$ & $\begin{array}{l}91 \% \\
9 \%\end{array}$ \\
\hline $\begin{array}{l}\text { Jenis komplikasi augmentasi penis } \\
\text { Nyeri } \\
\text { Ulkus yang disertai discharge } \\
\text { Ulkus }\end{array}$ & $\begin{array}{l}35 \% \\
30 \% \\
26 \%\end{array}$ \\
\hline $\begin{array}{l}\text { Skala nyeri }(\text { VAS }) \\
\text { Tak nyeri/ringan } \\
\text { Nyeri sedang } \\
\text { Nyeri berat }\end{array}$ & $\begin{array}{l}9 \% \\
78 \% \\
13 \%\end{array}$ \\
\hline $\begin{array}{l}\text { Lokasi kelainan komplikasi augmentasi } \\
\text { Preputium } \\
\text { Preputium sampai ke penile shaft } \\
\text { Preputium sampai suprapubik }\end{array}$ & $\begin{array}{c}52 \% \\
43 \% \\
5 \%\end{array}$ \\
\hline
\end{tabular}


Implan benda asing untuk augmentasi tersebut dapat berbentuk padat, semi-cair, atau cair. Terdapat empat praktek implantasi yang berbeda: 1) obyek benda asing padat; 2) semi-cair; 3) cairan yang diimplantasikan secara subkutis pada jaringan penis; dan 4) obyek benda asing ke dalam uretra. ${ }^{10-14}$ Bahan cair atau semi-cair yang disuntikkan di bawah kulit penis untuk augmentasi dapat berupa petroleum jelly, silikon, parafin, formalin, kolagen, asam hialuronik, alkohol, minyak mineral, logam merkuri, dan cairan transmisi. ${ }^{3,13,15-17}$

Para peneliti dalam bidang seks setuju bahwa pada prakteknya seluruh laki-laki di dunia sangat peduli akan ukuran penisnya, ${ }^{18}$ dan 'kepedulian' ini yang membuat seseorang individu termotivasi. Motivasi mengacu pada adanya kekuatan dorongan yang menggerakkan individu untuk berperi laku tertentu. Motivasi juga berhubungan dengan keinginan, dorongan, dan tujuan. ${ }^{19,20}$ Pada penelitian ini, dari data motivasi pada pasien yang ingin melakukan augmentasi didapatkan $61 \%$ yang memiliki motivasi internal yang terbukti dari hasil uji Fisher exact test yang menyatakan terdapat hubungan bermakna antara motivasi melakukan augmentasi penis dan kepuasan seksual. Berbeda halnya dengan hubungan antara pasca augmentasi (beserta komplikasi) dan kepuasaan seksual yang diuji dengan Fisher exact test yang menyatakan tidak terdapat hubungan bermakna antara tindakan augmentasi penis dan kepuasaan seksual.

Hasil penelitian mendapatkan bahwa pasien yang mengalami komplikasi akibat augmentasi penis sebesar $91 \%$, dengan jenis komplikasi berupa nyeri (35\%), diikuti ulkus yang disertai discharge (30\%), atau ulkus saja (26\%). Penebalan jaringan pada lokasi suntikan merupakan reaksi jaringan terhadap implan cair/semi-cair dan merupakan salah satu peradangan granulomatosa, dengan tampilan histologik umum yang ditentukan oleh jenis bahan cair atau semi-cair yang digunakan. ${ }^{15,21}$

Komplikasi serius sangat jarang terjadi bila volume cair murni steril digunakan hanya kecil, namun komplikasinya jauh lebih umum dan parah pada penggunaan dalam volume besar termasuk pemakaian bahan cair/semi-cair yang dipalsukan., 13,21-23 Keseluruhan pasien yag datang berobat ke Poliklinik Bedah menjalani proses augmentasi penis secara ilegal oleh tenaga non-paramedis tanpa alat yang steril sehingga proses mekanisme komplikasi pada lokasi suntikan dipicu oleh berbagai aktivasi antigenik bakteri atau virus yang tidak diketahui atau yang tersembunyi yang merupakan ciri aktivasi sel $\mathrm{T}$ Selain itu, semua jenis komplikasi dapat terjadi segera atau bertahun-tahun setelah perawatan. $1,3,7,10,13$

Berdasarkan lokasi kelainan didapatkan 52\% kasus di daerah preputium, $43 \%$ pada preputium sampai ke penis shaft dan 5\% dengan kelainan dari preputium sampai suprapubik. Polimer silikon bermigrasi setelah disuntikkan karena polimer ini memiliki sepuluh tingkat untuk bermigrasi, atau melayang, ke daerah-daerah yang menggantung. $1,9,13,21$

\section{SIMPULAN}

Berdasarkan hasil penelitian ini dapat disimpulkan bahwa terdapat hubungan bermakna antara motivasi dalam melakukan augmentasi penis dengan kepuasan seksual. Tidak terdapat hubungan antara pasca augmentasi penis dengan kepuasaan seksual. Hampir seluruh pasien pasca augmentasi berkomplikasi,

\section{DAFTAR PUSTAKA}

1. Afandi D, Djuandao I, Hertian S, Atmadja DS, Safitry O, Riyanto I. Temuan otopsi pada emboli silikon sistemik. Maj Kedokt Indon. 2008;58(7):267-71.

2. Ahmed I. 2011. Psychiatric manifestations of body dysmorphic disorder. Available from: http://emedicine.medscape. com/ article/291182

3. Arthaud JB. Silicone-induced penile sclerosing lipogranuloma. J Urol. 1973; 110(2):210.

4. Bair MJ, Robinson RL, Katon W, Kroenke K. Depression and pain comorbidity: a literature review. Arch Intern Med. 2003;163(20):2433-45.

5. Breivik H, Collett B, Ventafridda V, Cohen 
R, Gallacher D. Survey of chronic pain in Europe: prevalence, impact on daily life, and treatment. Eur J Pain. 2006;10(4):287.

6. Choudury N, Frame JD, Lewi HJE. Penile paraffinoma and a novel treatment. BJU International. 2003;91 1. DOI: 10.1046/j.1464-4096.2003.02940.x.

7. Ciancio SJ, Coburn M. Penile salvage for squamous cell carcinoma associated with mineral oil injection. J Urol. 2000; 164:1650.

8. McCaffery M, Pasero C. Pain Clinical Manual: Numeric Pain Rating Scale. St. Louis: Mosby Press, 1999; p. 16.

9. Mitchell WM. Self-insertion of uretheral foreign bodies. California: California College of Medicine University of California, 2005; p 479-86.

10. Bjurlin MA, Carlsen J, Grevious M, Jordan MD, Taylor A, Divakaruni $\mathbf{N}$, et al. Mineral oil-induced sclerosing lipogranuloma of the penis. J Clin Aesthet Dermatol. 2010;3(9):41-4.

11. Fischer N, Hauser S, Brede O, Fisang C, Müller S. Implantation of artificial penile nodules - a review of literature. $\mathbf{J}$ Sex Med. 2010;7:3565-71.

12. Griffith J, Horowitz D. Penile nodules in the penal system. Cutis. 2012;89(5): 237-9.

13. Kadouch JA, van Rozelaar L, Kanhai RJC, Sawor JH, Karim RB. Complications of penis or scrotum enlargement due to injections with permanent filling substances. Dermatol Surg. 2012;38 (7Pt 2):1244-50.

14. Lee T, Choi HR, Lee YT, Lee YH. Paraffinoma of the penis. Yonsei Med J. 1994;35(3):344-8.

15. Duffy DM. Liquid silicone for soft tissue augmentation. Dermatol Surg 2005;31:
1530-41.

16. Kang DH, Chung JH, Kim YJ, Lee HN, Cho SH, Chang TH, et al. Efficacy and safety of penile girth enhancement by autologous fat injection for patients with thin penises. Aesthetic Plast Surg 2012;36 (4):813-8

17. Moon DG, Kwak TI, Kim JJ. Glans penis augmentation using hyaluronic acid gel as an injectable filler. World $\mathbf{J}$ Mens Health. 2015;33(2):50-61.

18. Rosecker A, Bordás N, Pajor L, Bajory Z. Hungarian"jailhouse rock": inciden-ce and morbidity of vaseline self-injection of the penis. J Sex Med. 2013; 10(2): 509-15.

19. Kenney RD. Adolescent males who insert genitourinary foreign bodies: is psychiatric referral required? J Urol. 1988;32(2):127-30.

20. Mondaini N, Ponchietti R, Gontero P, Muir GH, Natali A, et al. Penile length is normal in most men seeking penile lengthening procedures. Int $\mathbf{J}$ Impot Res. 2002;14:283-6.

21. Zappi E, Barnett JG, Zappi M, Barnett CR. The long-term host response to liquid silicone injected during soft tissue augmentation procedures: a microscopic appraisal. Dermatol Surg 2007;33:S186-S192.

22. Klein AW. Tissue Augmentation in Clinical Practice (2nd ed). New York: Taylor \& Francis Group, 2006.

23. Merskey H, Addison RG, Beric A, Blumberg H, Bogduk N, Boivie J, et al. IASP task force in taxonomy pain terms. Classification of Chronic Pain Syndromes and Definitions of Pain Terms (2nd ed). Seattle: IASP Press, 1994; p. 206-13. 